\title{
Engagement of multi-professional residents in health*
}

\author{
Engagement de residentes multiprofissionais em saúde \\ Engagement de residentes multiprofesionales en salud
}

How to cite this article:

Rotta DS, Lourenção LG, Gonsalez EG, Teixeira PR, Gazetta CE, Pinto MH. Engagement of multi-professional residents in health. Rev Esc Enferm USP. 2019;53:e03437. DOI: http://dx.doi.org/10.1590/S1980-220X2018003103437

\author{
Daniela Salvagni Rotta ${ }^{1}$ \\ Luciano Garcia Lourenção ${ }^{2}$ \\ Elizangela Gianini Gonsalez ${ }^{1}$ \\ Priscila Regina Teixeira ${ }^{1}$ \\ Cláudia Eli Gazetta ${ }^{1}$ \\ Maria Helena Pinto ${ }^{1}$ \\ * Extracted from the dissertation: "Ansiedade, \\ depressão, bem-estar e trabalho de residentes \\ multiprofissionais da Faculdade de Medicina \\ de São José do Rio Preto/SP”, Faculdade de \\ Medicina de São José do Rio Preto, 2015. \\ 1 Faculdade de Medicina de São José do Rio \\ Preto, São José do Rio Preto, SP, Brazil. \\ 2 Universidade Federal do Rio Grande, Escola \\ de Enfermagem, Rio Grande, RS, Brazil.
}

\begin{abstract}
Objective: To evaluate the levels of engagement of multi-professional health residents of a higher education institution in the northwest of São Paulo. Method: A cross-sectional census study in which the Utrecht Work Engagement Scale was used to identify the level of relationship with work (Total score) through 17 questions distributed in the Vigor, Dedication and Absorption dimensions. Results: Participation of 50 professionals, of which $92.0 \%$ were female, median age of 24 years, $88.0 \%$ were single; $82.0 \%$ were satisfied with the program, and $56.0 \%$ had thought of giving up. Professionals satisfied with the program had high levels for Total Score (4.0) and Dedication (4.5), and average levels for Absorption (3.9) and Vigor (3.8). Those who reported dissatisfaction had average levels in all dimensions (Vigor: 3.2, Absorption: 3.5, Dedication: 3.5) and in the Total score (3.2), which are considered positive results. Conclusion: Professionals presented good levels of engagement in spite of dissatisfactions with the program. The results showed a good relationship between professionals and preceptors and supervisors, which reinforces that support and recognition of professional performance are important for strengthening the engagement, especially at the beginning of the career.
\end{abstract}

\section{DESCRIPTORS}

Work Engagement; Internship and Residency; Health Human Resource Training; Interprofessional Relations; Occupational Health.
Corresponding author:

Luciano Garcia Lourenção

Universidade Federal do Rio Grande

Escola de Enfermagem

Rua General Osório, s/no $4^{\circ}$ piso,

Centro, Campus da Saúde

CEP 96201-900 - Rio Grande, RS, Brazil

luciano.famerp@gmail.com
Received: 02/06/2018

Approved: 09/05/2018 


\section{INTRODUCTION}

The multi-professional health residency programs instituted in 2005 are post-graduation specialization courses (named lato sensu in Brazil) directed to health professions with the exception of medicine. The multi-professional residency is aimed at in-service education, guided by the principles and guidelines of the Unified Health System, and seeks the qualification of young professionals for meeting local and regional demands and realities ${ }^{(1)}$.

Although multi-professional residency is one of the best forms of professional qualification in the health area, the residence training is a period of much physical and emotional exhaustion for professionals ${ }^{(2)}$. Factors such as the exclusive dedication required by legislation ${ }^{(1)}$, and the insecurity, fear and pressure felt by newly graduated professionals generate uncertainty, anxiety and disillusionment that hinder the development of skills and abilities, and consequently compromise professional performance ${ }^{(2)}$.

Regardless of the great demands of work and the physical and emotional exhaustion inherent to the in-service training process in the multi-professional residency, some professionals do not show symptoms of exhaustion and, conversely, demonstrate pleasure through hard work and its demands. These professionals are described as engaged, i.e. engaged in their work $^{(3-4)}$.

The concept of engagement is recent, linked to positive psychology and has been associated with several constructs, but differs from other psychological states such as workaholism and job satisfaction. Engagement expresses activation (enthusiasm, attention, excitement, euphoria), and satisfaction implies satiation (contentment, calmness, serenity, relaxation). While engaged professionals see work as challenging and fun, workaholics feel a compulsive inner drive they cannot resist ${ }^{(3-5)}$.

In this context, engagement is an independent construct defined as a positive, satisfactory and work-related state of mind involving the professional's commitment and alignment with the environment and work activity. It is an affective, persistent and comprehensive cognitive state of motivational and social nature characterized by three dimensions, namely: Vigor, Absorption and Dedication ${ }^{(3-5)}$.

Vigor is defined by high levels of energy and mental resilience, desire to invest efforts at work and persistence to overcome difficulties. Dedication refers to being strongly involved and enthusiastic about work with feelings of significance, inspiration, pride, and challenge. Absorption corresponds to concentration with pleasure, so that time passes quickly, and the worker has difficulty with disconnecting from work ${ }^{(4-5)}$.

It is observed that "although there is no specific set for developing engagement, some factors found in the literature are associated with the concept, such as: social support; work performance; personal resources (such as self-efficacy and self-esteem); positive psychological capital; beliefs; type of coping used; optimism; organizational resources and demands; customer satisfaction and resilience" ${ }^{\prime(6)}$.
Given the shortage of epidemiological studies on engagement, the development of studies on this theme is relevant for obtaining normative scores that can be used as national or specific references of groups of workers, and for comparisons with individual or group engagement outcomes. Thus, professional categories, teams, departments or groups of professionals can be classified in levels of engagement varying from very low to very high ${ }^{(5)}$.

In Brazil, although studies on engagement with health professionals are recent, they showed satisfactory results, especially in the dedication dimension, and a positive relationship between professionals and work ${ }^{(7-8)}$. For some authors, studies on engagement may contribute to understanding the aspects related to the development of this construct and favor the organization and improvement of work processes in health services ${ }^{(7-10)}$.

In this context, studying engagement with multi-professional residents in health can identify strengths and weaknesses in the relationship of professionals with the training environment, thereby contributing to strengthening these programs and improving professional training for the Brazilian health system.

In view of the above, the aim of this study was to evaluate the levels of engagement in the work of professionals enrolled in multi-professional health residency programs of a public institution in the inland of the state of São Paulo.

\section{METHOD}

\section{TyPE OF STUDY}

Cross-sectional census study.

\section{SCENARIO}

Performed with professionals from different areas, enrolled in multi-professional health residency programs of a public institution in the inland of the state of São Paulo.

The study population included all professionals enrolled in multi-professional health residency programs offered by the institution, who agreed to participate in the study after being informed about its objectives and purposes, totaling 50 professionals.

\section{DATA COLLECTION}

Data were collected from November 2013 to February 2014 with use of two self-applied instruments. The first one was prepared by the authors for characterization of professionals' profile, and contained personal data, such as professional category, gender, age, marital status, family income, if the person is satisfied and has already thought about giving up the program. The second was the Brazilian version of the Utrecht Work Engagement Scale (UWES) validated by Vazques et al. ${ }^{(11)}$, which allows the identification of the level of relationship with work (Total score) by means of 17 questions distributed in the dimensions of Vigor (high levels of energy and resistance, desire to invest effort, not feeling fatigued easily, and persistence in the face of difficulties), Dedication (sense of meaning of work, feeling enthusiastic and proud about the job and inspired and challenged by it) and Absorption 
(being totally and happily immersed at work, having difficulties detaching from it, so that time passes quickly and the professional forgets everything that is around $)^{(11-12)}$.

The consistency of data was evaluated by Cronbach's Alpha Coefficient. The calculations of scores of engagement dimensions were performed according to the statistical model proposed in the UWES Preliminary Manual. Minimum, maximum, median, mean ( \pm standard deviation) values were presented, and 95\% confidence intervals were set for each UWES dimension. After calculating the scores of each dimension, the values obtained were interpreted according to the decoding of the UWES Preliminary Manual $^{(12)}$, in which 0 to $0.99=$ Very Low; 1 to $1.99=$ Low; 2 to $3.99=$ Average; 4 to $4.99=$ High; 5 to $6=$ Very High .

\section{ANALYSIS AND PROCESSING OF DATA}

Data analysis was performed with the Statistical Package for Social Sciences (SPSS), version 17.0. For the comparisons of mean scores of the UWES dimensions, the F-test was used in analysis of variance (ANOVA) by considering a significance level of $5 \%(p<0.05)$.

\section{ETHICAL ASPECTS}

The study was approved by the Research Ethics Committee of the Faculdade de Medicina de São José do Rio Preto (FAMERP) under number 460.331 from 11/12/2013, and were respected the ethical precepts of research involving human beings as established by Resolution 466/12 of the National Health Council. All participants signed the Informed Consent form.

\section{RESULTS}

Fifty professionals from different categories participated in the study, and most were nurses (30.0\%). There was a prevalence of the female gender $(92.0 \%)$, the age range varied from 20 to 30 years, and the median age was 24 years. Regarding marital status, $88.0 \%$ of respondents were single. Twenty-eight professionals (56.0\%) had family income of 2 to 5 minimum wages and nine (18.0\%), above 10 minimum wages. Forty-one (82.0\%) professionals reported they were satisfied with the program, although 28 (56.0\%) had already considered giving up (Table 1).

Table 2 presents the results of the engagement evaluation from the distribution of minimum, maximum, median, mean values ( \pm standard deviation) and $95 \%$ confidence intervals according to the UWES dimensions. The mean of the total score was $3.9( \pm 1.0)$ points, classified as average. The Dedication dimension had a high score with a mean of 4.3 $( \pm 1.2)$ points.

As observed in Table 3, Cronbach's Alpha Coefficient ranged from 0.788 to 0.938 , indicating the reliability of results. The distribution of the number of professionals at each level of engagement classification showed that in the Vigor dimension, 46.9\% ( $n=23)$ of professionals presented high or very high levels of engagement; in the Absorption dimension, $50.0 \%(n=25)$ of professionals had high or very high engagement levels; and in the Dedication dimension, these levels were found in $66.0 \%(n=33)$ of professionals. For the Total score, the average level was observed in $44.9 \%$ $(n=22)$ of professionals, while $53.0 \%(n=26)$ had high or very high levels.

Table 1 - Sociodemographic characteristics of professionals studied - São José do Rio Preto, SP, Brazil, 2014.

\begin{tabular}{|c|c|c|c|}
\hline & & $\mathbf{n}$ & $\%$ \\
\hline \multirow[t]{10}{*}{ Professional category } & Nursing & 15 & 30.0 \\
\hline & Pharmacy & 02 & 4.0 \\
\hline & Physiotherapy & 05 & 10.0 \\
\hline & Biological Sciences & 02 & 4.0 \\
\hline & Dentistry & 02 & 4.0 \\
\hline & Speech-language Pathology & 03 & 6.0 \\
\hline & Nutrition & 09 & 18.0 \\
\hline & Psychology & 04 & 8.0 \\
\hline & Veterinary Medicine & 01 & 2.0 \\
\hline & Occupational Therapy & 07 & 14.0 \\
\hline \multirow[t]{2}{*}{ Gender } & Male & 4 & 8.0 \\
\hline & Female & 46 & 92.0 \\
\hline \multirow[t]{3}{*}{ Age group } & $20-25$ years & 38 & 76.0 \\
\hline & 26 - 30 years & 10 & 20.0 \\
\hline & No answer & 02 & 4.0 \\
\hline \multirow[t]{3}{*}{ Marital status } & Married & 05 & 10.0 \\
\hline & Single & 44 & 88.0 \\
\hline & Others & 01 & 2.0 \\
\hline \multirow{3}{*}{$\begin{array}{l}\text { Family income } \\
\text { (minimum wage)* }\end{array}$} & 2 to 5 & 28 & 56.0 \\
\hline & 6 to 10 & 13 & 26.0 \\
\hline & More than 10 & 09 & 18.0 \\
\hline \multirow[t]{2}{*}{ Satisfied with program } & Yes & 41 & 82.0 \\
\hline & No & 09 & 18.0 \\
\hline \multirow[t]{2}{*}{ Thought of giving up the program } & Yes & 28 & 56.0 \\
\hline & No & 22 & 44.0 \\
\hline
\end{tabular}

*Minimum wage value at the time of data collection: $\mathrm{R} \$ 678.00$. 
Table 2 - Evaluation of engagement according to dimensions of the Utrecht Work Engagement Scale - São José do Rio Preto, SP, Brazil, 2014.

\begin{tabular}{|c|c|c|c|c|c|c|c|c|}
\hline UWES scores* & $\mathbf{n}$ & ${ }^{+} \mathrm{Min}$ & ${ }^{\ddagger} \operatorname{Max}$ & ${ }^{\mathrm{s}} \mathrm{Md}$ & Mean $\left( \pm s d^{\prime} \mid\right)$ & $\mathrm{Cl}(95 \%)^{9}$ & Interpretation & P-value \\
\hline Vigor & 49 & 0.3 & 5.5 & 3.8 & $3.7 \pm 1.0$ & $3.4-4.0$ & Average & 0.118 \\
\hline Absorption & 49 & 1.0 & 5.3 & 3.8 & $3.8 \pm 1.0$ & $3.5-4.1$ & Average & 0.083 \\
\hline Dedication & 49 & 0.4 & 6.0 & 4.6 & $4.3 \pm 1.2$ & $3.9-4.6$ & High & 0.047 \\
\hline Total score & 49 & 0.6 & 5.4 & 4.1 & $3.9 \pm 1.0$ & $3.6-4.2$ & Average & 0.110 \\
\hline
\end{tabular}

*UWES: Utrecht Work Engagement Scale; †Min.: minimum; ¥Max.: maximum; §Md: median; ||SD: standard deviation; $₫$ CI 95\%: 95\% confidence interval.

Table 3 - Classification of the level of engagement of the Utrecht Work Engagement Scale dimensions - São José do Rio Preto, SP, Brazil, 2014.

\begin{tabular}{|c|c|c|c|c|c|c|c|c|c|c|c|c|c|}
\hline \multirow{3}{*}{ UWES dimensions* } & \multirow{3}{*}{$\mathbf{n}$} & \multirow{3}{*}{$\begin{array}{l}\text { Cronbach's } \\
\text { alpha }\end{array}$} & \multirow{3}{*}{ Mean score } & \multicolumn{10}{|c|}{ Classification of level of engagement at work } \\
\hline & & & & \multicolumn{2}{|c|}{ Very low } & \multicolumn{2}{|c|}{ Low } & \multicolumn{2}{|c|}{ Average } & \multicolumn{2}{|c|}{ High } & \multicolumn{2}{|c|}{ Very high } \\
\hline & & & & $\mathbf{n}$ & $\%$ & $\mathbf{n}$ & $\%$ & $\mathbf{n}$ & $\%$ & $\mathbf{n}$ & $\%$ & $\mathbf{n}$ & $\%$ \\
\hline Vigor & 49 & 0.836 & 3.8 & 01 & 2.0 & 01 & 2.0 & 24 & 49.0 & 18 & 36.7 & 05 & 10.2 \\
\hline Absorption & 50 & 0.788 & 3.8 & - & - & 01 & 2.0 & 24 & 48.0 & 18 & 36.0 & 07 & 14.0 \\
\hline Dedication & 50 & 0.912 & 4.6 & 01 & 2.0 & - & - & 16 & 32.0 & 13 & 26.0 & 20 & 40.0 \\
\hline Total score & 49 & 0.938 & 4.1 & 01 & 2.0 & - & - & 22 & 44.9 & 20 & 40.8 & 06 & 12.2 \\
\hline
\end{tabular}

*UWES: Utrecht Work Engagement Scale.

The evaluation of engagement according to professional categories (Table 4), showed that residents of Physical Therapy and Nutrition presented high scores (high or very high) in all dimensions of the UWES. Most professional categories expressed high levels of engagement in the Dedication dimension.

As observed in Table 5, although most professionals (82.0\%) reported being satisfied with the multi-professional residency program, $56.0 \%$ of them have already considered giving up at some point.
The evaluation of residents' levels of engagement according to satisfaction with the program showed that professionals who said they were satisfied with the program had a high level of Dedication and average level of Absorption and Vigor, and a high Total score $(4.0 ; \pm 1.0)$.

Those who expressed intention to give up the residency program, showed an average level of engagement in all dimensions of UWES. Professionals who never thought about giving up the program had high levels of Vigor and Absorption, and very high levels of Dedication, so the Total score was high $(4.6 ; \pm 0.6)$.

Table 4 - Evaluation of engagement according to professional categories - São José do Rio Preto, SP, Brazil, 2014.

\begin{tabular}{|c|c|c|c|c|c|}
\hline \multirow{2}{*}{ Professional category } & & \multicolumn{4}{|c|}{ UWES dimensions* } \\
\hline & & Vigor & Absorption & Dedication & Total score \\
\hline \multirow{2}{*}{ Nursing } & Mean $\left( \pm \mathrm{sd}^{+}\right)$ & $3.9( \pm 1.4)$ & $4.0( \pm 1.0)$ & $4.1( \pm 1.7)$ & $3.9( \pm 1.2)$ \\
\hline & Interpretation & Average & High & High & Average \\
\hline \multirow{2}{*}{ Pharmacy } & Mean $( \pm \mathrm{sd})$ & $3.5( \pm 2.1)$ & $3.5( \pm 2.1)$ & $4.0( \pm 1.4)$ & $3.5( \pm 2.1)$ \\
\hline & Interpretation & Average & Average & High & Average \\
\hline \multirow{2}{*}{ Physiotherapy } & Mean $( \pm s d)$ & $4.4( \pm 0.5)$ & $4.4( \pm 0.9)$ & $5.6( \pm 0.5)$ & $4.6( \pm 0.5)$ \\
\hline & Interpretation & High & High & Very high & High \\
\hline \multirow{2}{*}{ Biological Sciences } & Mean $( \pm s d)$ & $3.5( \pm 0.7)$ & $3.5( \pm 0.7)$ & $4.1( \pm 1.0)$ & $3.7( \pm 0.8)$ \\
\hline & Interpretation & Average & Average & High & Average \\
\hline \multirow{2}{*}{ Dentistry } & Mean $( \pm s d)$ & $2.5( \pm 0.7)$ & $2.5( \pm 0.7)$ & $3.1( \pm 0.9)$ & $2.8( \pm 0.8)$ \\
\hline & Interpretation & Average & Average & Average & Average \\
\hline \multirow{2}{*}{ Speech-language Therapy } & Mean $( \pm s d)$ & $3.0( \pm 1.0)$ & $3.3( \pm 1.5)$ & $4.7( \pm 0.6)$ & $3.7( \pm 1.2)$ \\
\hline & Interpretation & Average & Average & High & Average \\
\hline \multirow{2}{*}{ Nutrition } & Mean $( \pm s d)$ & $4.1( \pm 1.0)$ & $4.0( \pm 0.7)$ & $4.9( \pm 0.8)$ & $4.4( \pm 0.9)$ \\
\hline & Interpretation & High & High & High & High \\
\hline \multirow{2}{*}{ Psychology } & Mean $( \pm \mathrm{sd})$ & $3.8( \pm 0.9)$ & $3.5( \pm 1.7)$ & $4.0( \pm 1.8)$ & $3.8( \pm 1.5)$ \\
\hline & Interpretation & Average & Average & High & Average \\
\hline \multirow{2}{*}{ Veterinary Medicine } & Mean $( \pm s d)$ & $2.8(\#)$ & $3.5(\#)$ & $2.8(\#)$ & $3.1(\#)$ \\
\hline & Interpretation & Average & Average & Average & Average \\
\hline \multirow{2}{*}{ Occupational Therapy } & Mean $( \pm \mathrm{sd})$ & $3.4( \pm 0.8)$ & $3.3( \pm 0.9)$ & $3.9( \pm 1.2)$ & $3.6( \pm 1.0)$ \\
\hline & Interpretation & Average & Average & Average & Average \\
\hline P-value & & 0,545 & 0.532 & 0.271 & 0.651 \\
\hline
\end{tabular}

*UWES: Utrecht Work Engagement Scale; †sd: standard deviation. \#Category with only one professional. 
Table 5 - Evaluation of engagement according to satisfaction with the program and the desire to give up reported by professionals São José do Rio Preto, SP, Brazil, 2014.

\begin{tabular}{|c|c|c|c|c|c|}
\hline UWES dimension ${ }^{*}$ & Satisfaction with program & $\mathbf{n}$ & Mean \pm sd $^{+}$ & Interpretation & P-value \\
\hline \multirow{2}{*}{ Vigor } & Yes & 41 & $3.8 \pm 1.1$ & Average & \multirow{2}{*}{0.051} \\
\hline & No & 8 & $3.2 \pm 0.1$ & Average & \\
\hline \multirow{2}{*}{ Absorption } & Yes & 41 & $3.9 \pm 1.0$ & Average & \multirow{2}{*}{0.235} \\
\hline & No & 9 & $3.5 \pm 0.9$ & Average & \\
\hline \multirow{2}{*}{ Dedication } & Yes & 41 & $4.5 \pm 1.1$ & High & \multirow{2}{*}{0.008} \\
\hline & No & 9 & $3.6 \pm 1.0$ & Average & \\
\hline \multirow{2}{*}{ Total score } & Yes & 41 & $4.0 \pm 1.0$ & High & \multirow{2}{*}{0.008} \\
\hline & No & 8 & $3.2 \pm 0.6$ & Average & \\
\hline UWES dimension ${ }^{*}$ & Thought of giving up & $\mathbf{n}$ & Mean \pm sd $^{+}$ & Interpretation & P-value \\
\hline \multirow{2}{*}{ Vigor } & Yes & 28 & $3.2 \pm 1.0$ & Average & \multirow{2}{*}{$<0.001$} \\
\hline & No & 21 & $4.3 \pm 0.6$ & High & \\
\hline \multirow{2}{*}{ Absortion } & Yes & 28 & $3.3 \pm 1.0$ & Average & \multirow{2}{*}{$<0.001$} \\
\hline & No & 22 & $4.4 \pm 0.6$ & High & \\
\hline \multirow{2}{*}{ Dedication } & Yes & 28 & $3.7 \pm 1.2$ & Average & \multirow{2}{*}{$<0.001$} \\
\hline & No & 22 & $5.0 \pm 0.7$ & Very high & \\
\hline \multirow{2}{*}{ Total score } & Yes & 28 & $3.4 \pm 1.0$ & Average & \multirow{2}{*}{$<0.001$} \\
\hline & No & 21 & $4.6 \pm 0.6$ & High & \\
\hline
\end{tabular}

*UWES: Utrecht Work Engagement Escale; $\uparrow$ sd: standard deviation.

\section{DISCUSSION}

The profile of professionals of this study - women, young and single adults - corroborates national and international studies on engagement among health professionals ${ }^{(7-8,13-15)}$. The prevalence of nursing professionals is consistent with that found in other in-service training programs ${ }^{(2,8,16)}$ and inherent to the distribution of the number of vacancies offered by the study institution for different professional categories. Of the 50 vacancies offered annually, 18 are destined for different nursing specialties ${ }^{(8,17)}$.

The levels of engagement presented by multi-professional residents of this study are similar to those found in Brazilian studies with pediatric medical residents ${ }^{(7)}$ and with professionals of improvement programs ${ }^{(8)}$, which shows professionals' commitment and positive alignment with the work environment.

The high level of Dedication presented by multi-professional residents is a strong point in the relationship of these professionals with the training environment, and shows their involvement and enthusiasm with work, as mentioned in other studies ${ }^{(7-8,10,15)}$. The presence of highly dedicated professionals in multi-professional residency programs can be explained by the quality of the service, the professional qualification process, and the rigorous selection process that includes objective evidence, curricular analysis and interview for filling the 50 vacancies offered annually.

According to the literature, engagement is a relatively stable phenomenon that can be explained by the presence of specific organizational and work characteristics ${ }^{(18)}$. This construct is not focused on a single objective, event or situation, but characterized by energy, involvement and professional effectiveness, which are beneficial to workers, i.e., lead to well-being, since working motivated by factors or core values is quite satisfactory ${ }^{(13)}$. In this context, professionals with high levels of engagement will contribute positively to the care provided to health services users.
Although the literature highlights the stressful nature of professional residency programs that make adaption and professional performance difficult ${ }^{(2,19-20)}$, this study demonstrated that most professionals have high or very high levels of engagement, especially in Dedication and Absorption dimensions, that is, they have a positive relationship with work (Total score), concentration (Absorption) and involvement (Dedication ) with the work activity. These results confirm those found among Saudi ${ }^{(14)}$ and Irish nurses ${ }^{(15)}$ by reinforcing that engagement is influenced by organizational variables and engaged workers tend to be healthier and more efficient ${ }^{(21)}$.

Recent studies have shown that involvement at work can vary from person to person, and professionals may show higher or lower levels of engagement in day to day depending on what happens on that particular day ${ }^{(18,22)}$. Furthermore, professionals with high levels of engagement can cope better with work demands as they have energy, are connected to work, and feel able to deal with the less positive aspects of the work activity ${ }^{(23)}$.

However, engagement is not just an individual phenomenon, but related to the group in which the worker is inserted. Workers of some teams or parts of an organization may be more engaged than others ${ }^{(5,22)}$, as shown by a study with Portuguese nurses from hospital units, who presented average and high levels of engagement varying between regions, hospitals and care units ${ }^{(24)}$. These data corroborate the results observed in this study among the different professional categories of residents.

The prevalence of professionals satisfied with the multiprofessional residency program was an evident positive factor in this study. These professionals had significantly higher levels of engagement than dissatisfied professionals, especially in the Dedication dimension. According to the literature, the valorization of workers' performance and creativity by their superiors and the financial aspect can be associated to satisfaction and well-being at work ${ }^{(25)}$, and contribute to higher engagement. For the multi-professional residents studied, the remuneration received at the beginning of the career and professional recognition may be reasons for the mentioned satisfaction. 
Engagement is proportionately related to performance at work and is structured as professionals like or dislike their work $^{(26)}$. Studies with health and education professionals show high mean values in all dimensions (Vigor, Dedication and Absorption) of the UWES, which demonstrates that professionals' satisfaction with work is significant and positively related to the levels of engagement ${ }^{(14,27-28)}$.

Significantly higher engagement levels presented by professionals who never thought about giving up the program confirm the literature that points positive work involvement as an important factor for the workforce worldwide, and its absence can cause great emotional exhaustion. High engagement is associated with success factors, such as increased worker performance and efficiency, higher productivity, safety, customer service and professional retention, customer satisfaction and loyalty, and profitability ${ }^{(22)}$.

In addition, engaged workers are healthier, experience positive emotions more often, create their work resources and can pass on their commitment to others ${ }^{(26)}$.

Organizational strategies that promote a cohesive and healthy work environment with reduction of stress related to care practice, professional recognition, supportive relationships, good communication, teamwork and positive experiences with teachers and preceptors can guarantee multiprofessional residents' satisfaction, improve their levels of Vigor (energy and resilience), Absorption (concentration) and Dedication (involvement and enthusiasm) ${ }^{(29)}$.

Therefore, by meeting the needs of young professionals who enter multi-professional residency programs, it is possible to stimulate a higher engagement ${ }^{(9)}$ and contribute to professionals' better qualification for serving health services users at the end of the training process.
The main limitations of this study were the lack of other studies on engagement with health professionals and the sample restricted to a single educational institution. These factors highlight the need to broaden the scientific research related to the subject with a greater number of professionals and institutions by deepening the analysis between the different professional categories and their labor specificities, and contributing to the knowledge on engagement among multi-professional residents in health. Moreover, in order to make the evaluation of engagement among residents more effective, the causes of dissatisfaction mentioned by professionals must be investigated.

\section{CONCLUSION}

The study showed that multi-professional residents presented good levels of engagement, in spite of dissatisfactions with the program. The results showed a good relationship between professionals and preceptors and supervisors, which reinforces that support and recognition of professional performance are important for strengthening of engagement, especially in the beginning of the career.

Professionals' satisfaction and their levels of engagement can be improved through changes in the work environment with professional valorization and collaboration, greater autonomy of the resident, support and integration with teachers and preceptors that facilitate the work process and make it more participatory, thereby improving performance, productivity and quality in community service.

Finally, when professionals with high levels of engagement exercise their work activities, they will contribute to improvement of patient safety, quality of care, and better service performance.

\section{RESUMO}

Objetivo: Avaliar os níveis de engagement de residentes multiprofissionais em saúde de uma instituição de ensino superior do noroeste paulista. Método: Estudo censitário transversal, que utilizou a Utrecht Work Engagement Scale para identificar o nível de relação com o trabalho (Escore geral) por meio de 17 questões distribuídas nas dimensões Vigor, Dedicação e Absorção. Resultados: Participaram 50 profissionais. $92,0 \%$ do sexo feminino, idade mediana de 24 anos, $88,0 \%$ solteiros; $82,0 \%$ referiram-se satisfeitos com o programa, e $56,0 \%$ já pensaram em desistir. Os profissionais satisfeitos com o programa apresentaram Escore geral $(4,0)$ e Dedicação $(4,5)$ altos, e níveis médios de Absorção $(3,9)$ e Vigor $(3,8)$. Os que se referiram insatisfeitos apresentaram níveis médios em todas as dimensões (Vigor: 3,2; Absorção: 3,5; Dedicação: 3,5) e no o Escore geral (3,2), resultados considerados positivos. Conclusão: Os profissionais apresentaram bons níveis de engagement, mesmo havendo insatisfações com o programa. Os resultados mostraram boa relação dos profissionais com preceptores e supervisores, reforçando que o apoio e o reconhecimento do desempenho dos profissionais são importantes para o fortalecimento do engagement, principalmente no início da carreira.

\section{DESCRITORES}

Engajamento no Trabalho; Internato e Residência; Capacitação de Recursos Humanos em Saúde; Relações Interprofissionais; Saúde do Trabalhador.

\section{RESUMEN}

Objetivo: Evaluar los niveles de engagement (compromiso) de residentes multiprofesionales en salud de un centro de enseñanza superior del noroeste del Estado de São Paulo. Método: Estudio censal transversal, que utilizó la Utrecht Work Engagement Scale para identificar el nivel de relación con el trabajo (Score general) por medio de 17 cuestiones distribuidas en las dimensiones Vigor, Dedicación y Absorción. Resultados: Participaron 50 profesionales. E1 92,0\% del sexo femenino, edad mediana de 24 años, el 88,0\% solteros; el 82,0\% se refirieron satisfechos con el programa; y el 56,0\% ya pensaron en desistir. Los profesionales satisfechos con el programa presentaron Score general $(4,0)$ y Dedicación $(4,5)$ altos, y niveles medios de Absorción $(3,9)$ y Vigor $(3,8)$. Los que se refirieron insatisfechos presentaron niveles medios en todas las dimensiones (Vigor: 3,2; Absorción: 3,5; Dedicación: 3,5) y en el Score general (3,2), resultados considerados positivos. Conclusión: Los profesionales presentaron buenos niveles de engagement, aun habiendo insatisfacciones con el programa. Los resultados mostraron buena relación de los profesionales con preceptores y supervisores, reforzando que el apoyo y el reconocimiento del desempeño de los profesionales son importantes para el fortalecimiento del engagement, especialmente en el inicio de la carrera.

\section{DESCRIPTORES}

Compromiso Laboral; Internado y Residencia; Educación en Salud; Capacitación de Recursos Humanos en Salud; Relaciones Interprofesionales; Salud Laboral. 


\section{REFERENCES}

1. Brasil. Lei n. 11.129, de 30 de junho de 2005. Institui a Residência em Área Profissional de Saúde e cria a Comissão Nacional de Residência Multiprofissional em Saúde - CNRMS. Diário Oficial da União, Brasília, 1 jul. 2005. Seção 1, p. 1.

2. Lourenção LG, Moscardini AC, Soler ZASG. Quality of life of non-medical residents professionals. J Nurs UFPE on line [Internet]. 2013 [cited 2018 Jan 24];7(11):6336-45. Available from: https://periodicos.ufpe.br/revistas/revistaenfermagem/article/view/12277.

3. Schaufeli WB, Salanova M, González-romá V, Bakker AB. The measurement of engagement and burnout: a two sample confirmatory factor analytic approach. J Happiness Stud. 2002;3(1):71-92. DOI: https://doi.org/10.1023/A:1015630930326

4. Porto-Martins PC, Basso-Machado PG, Benevides-Pereira AMT. Engagement no trabalho: uma discussão teórica. Fractal Rev Psicol. 2013;25:(3):629-44. DOI: http://dx.doi.org/10.1590/S1984-02922013000300013

5. Schaufeli WB. Work engagement: what do we know and where do we go? Rom J Appl Psychol. 2012;14(1):3-10.

6. Basso-Machado PG, Porto-Martins PC, Amorim C. Engagement no trabalho entre profissionais da educação. Rev Intersaberes [Internet]. 2012 [citado 2018 ago. 23];7(13):193-214. Disponível em: https://www.uninter.com/intersaberes/index.php/revista/article/view/257/166

7. Teixeira PR, Lourenção LG, Gazetta CE, Gonzalez EG, Rotta DS, Pinto MH et al. Engagement no trabalho em residentes médicos de pediatria. Rev Bras Educ Med [Internet]. 2017 [citado 2018 jan. 24];4(1):126-33. Disponível em: http://www.scielo.br/scielo. php?pid=S0100-55022017000100126\&script=sci_abstract\&tlng=pt

8. Gonzalez EG, Lourenção LG, Teixeira PR, Rotta DS, Gazetta CE, Pinto MH. Engagement no trabalho em profissionais de programas de aprimoramento profissional em saúde. Cad Bras Ter Ocup [Internet]. 2017 [citado 2018 jan. 24];25(3):509-17. Disponível em: http:// www.cadernosdeterapiaocupacional.ufscar.br/index.php/cadernos/article/view/1734

9. Lepistö S, Alanen S, Aalto P, Järvinen P, Leino K, Mattila E, et al. Healthcare professionals' work engagement in Finnish university hospitals. Scand J Caring Sci. 2017 Oct 10; DOI: https://doi.org/10.1111/scs.12538 [Epub ahead of print].

10. Ortiz FA, Jaramillo VA. Factores de riesgo psicosocial y compromiso (engagement) com el trabajo en una organización del sector salud de la ciudad de Cali, Colombia. Act Colom Psicol [Internet]. 2012 [citado 2018 Ene 24];16(1):43-56. Disponible en: http://www.scielo.org. co/scielo.php?pid=S0123-91552013000100005\&script=sci_abstract\&tlng=es

11. Vazquez ACS, Magnan ES, Pacico JC, Hutz CS, Schaufeli WB. Adaptation and validation of the Brazilian version of the Utrecht Work Engagement Scale. Psico USF. 2015;20(2):207-17. DOI: http://dx.doi.org/10.1590/1413-82712015200202

12. Agnst R, Benevides-Pereira AMT, Porto-Martins PC. Utrecht Work Engagement Scale. Curitiba: GEPEB; 2009.

13. Merino CF, Gallardo RY. Describiendo el engagement en profesionales de enfermería de atención primaria de salud. Cienc Enferm [Internet]. 2014 [citado 2018 Ene 24];20(3):131-40. Disponible en: https://scielo.conicyt.cl/scielo.php?script=sci_arttext\&pid=S0717$95532014000300012 \& \operatorname{lng}=$ en\&nrm=iso\&tlng=en

14. Aboshaiqah AE, Hamadi HY, Salem OA, Zakari NMA. The work engagement of nurses in multiple hospital sectors in Saudi Arabia: a comparative study. J Nur Manag. 2016;24(4):540-8. DOI: http://dx.doi.org/10.1111/jonm.12356.

15. White M, Wells JSG, Butterworth T. The impact of a large-scale quality improvement programme on work engagement: preliminary results from a national cross-sectional-survey of the 'Productive Ward'. Int J Nurs Stud. 2014;51(12):1634-43. DOl: http://dx.doi.org/10.1016/j. ijnurstu.2014.05.002

16. Goulart CT, Silva RM, Bolzan MEO, Guido LA. Perfil sociodemográfico e acadêmico de residentes multiprofissionais de uma universidade pública. Rev Rene [Internet]. 2012 [citado 2018 jan. 24]; 13(1):178-86. Disponível em: http://www.periodicos.ufc.br/rene/article/ viewFile/3791/2994

17. Gonsalez EG, Lourenção LG, Teixeira PR, Rotta DS, Gazetta CE, Pinto MH. Ansiedade e depressão entre profissionais de programas de aprimoramento profissional. Rev Port Enferm Saúde Mental [Internet]. 2017 [citado 2018 fev. 06]; (18):51-58. Disponível em: http://www. scielo.mec.pt/pdf/rpesm/n18/n18a08.pdf

18. Mukkavilli M, Kulkarni S, Doshi D, Reddy S, Reddy P, Reddy S. Assessment of work engagement among dentists in Hyderabad. Work. 2017;58(3):333-40. DOI: https://doi.org/10.3233/WOR-172630

19. Rotta DS, Pinto MH, Lourenção LG, Teixeira PR, Gonsalez EG, Gazetta CE. Níveis de ansiedade e depressão entre residentes multiprofissionais em saúde. Rev Rene [Internet]. 2016 [cited 2018 Jan 24];17(3):372-7. Disponível em: http://periodicos.ufc.br/rene/ article/view/3471

20. Franco GP, Barros ALBL, Nogueira-Martins LA, Zeitoun SS. Burnout in nursing residents. Rev Esc Enferm USP [Internet]. 2011 [cited 2018 Jan 24];45(1):12-8. Available from: http://www.scielo.br/scielo.php?script=sci_arttext\&pid=S0080-62342011000100002\&lng=en\&nrm= iso\&tlng=en

21. Setti I, Argentero P. Organizational features of workplace and job engagement among Swiss healthcare workers. Nurs Health Sci. 2011;13(4):425-32. DOl: https://doi.org/10.1111/j.1442-2018.2011.00636.x

22. Jeve YB, Oppenheimer C, Konje J. Employee engagement within the NHS: a cross-sectional study. Int J Health Policy Manag. 2015;4(2):8590. DOI: https://doi.org/10.15171/JJPM.2015.12

23. Silva MI, Astorga MCM. Engagement e burnout em professores portugueses. Int J Developm Educ Psychol [Internet]. 2012 [citado 2018 fev. 06];1(4):63-71. Disponível em: http://www.redalyc.org/pdf/3498/349832337006.pdf

24. Pinto AM, Jesus EH, Mendes AMOC, Fronteira ISE. Estudo RN4Cast em Portugal: work engagement dos enfermeiros. Rev Investig Enferm. $2015 ; 10(2): 26-37$.

25. Breevaart K, Bakker AB. How leaders influence their followers' work engagement. Eur Work Org Psychol Pract. 2013;5:31-5.

26. Kubota K, Shimazu A, Kawakami N, Takahashi M, Nakata A, Shcaufeli WB. Distinción empírica entre engagement y trabajolismo en enfermeras hospitalarias de Japón: efecto sobre la calidad del sueño y el desempeño laboral. Cienc Trab [Internet]. 2011 [citado 2018 Ene 24];13(41):152-7. Disponible en: https://www.ncbi.nlm.nih.gov/pmc/articles/PMC4705841/ 
27. Silva M, Queirós C, Cameira M, Vara N, Galvão A. Burnout e engagement em profissionais de saúde do interior-norte de Portugal. Psic Saúde Doença [Internet]. 2015 [citado 2018 fev. 06];16(3):286-99. Disponível em: http://www.scielo.mec.pt/pdf/psd/v16n3/v16n3a02.pdf

28. Araújo I, Esteves R. Engagement em docentes do ensino superior: uma abordagem exploratória. Enferm Universit. 2016;13(2):73-9. DOI: https://doi.org/10.1016/j.reu.2016.03.006

29. Jenaro C, Flores N, Orgaz MB, Cruz M. Vigour and dedication in nursing professionals: towards a better understanding of work engagement. J Adv Nurs. 2011;67(4):865-75. DOI: https://doi.org/10.1111/j.1365-2648.2010.05526.x.

Faculdade de Medicina de São José do Rio Preto, Research Grant Program 2013/2014. 